\title{
A BAHIA NA CRISE POLÍTICA DO ANTIGO REGIME \\ (1808-1815)
}

\author{
Maria Aparecida Silva de Sousa ${ }^{1}$ \\ Depto. de História da Universidade Estadual do Sudoeste da Bahia
}

\begin{abstract}
Resumo
$\mathrm{O}$ artigo discute a transferência da família real para a América portuguesa em meio à crise política que assolou a península ibérica nas primeiras décadas de 1800 . A passagem do príncipe regente pela Bahia, em 1808, e sua posterior fixação no Rio de Janeiro, inauguraram um período de profundas alterações na capitania condizentes com uma conturbada conjuntura de guerras e de desestruturação do Antigo Regime, cujo papel desempenhado pelo conde dos Arcos e a elevação do Brasil a Reino adquirem relevância.
\end{abstract}

\section{Pallavras-chaves}

Bahia $\bullet$ crise do Antigo Regime $\bullet$ história política.

\section{Abstract}

The article argues the transference of the real family for Portuguese America in way to the crisis politics that devastated the Iberian peninsula in the first decades of 1800 . The passage of the prince regent for the Bahia, in 1808, and its posterior setting in Rio de Janeiro, had inaugurated a period of deep alterations in the captainship coherent with a conjuncture of wars and crisis of the Ancient Regime, whose role played for conde dos Arcos and elevation of Brazil to Kingdom acquire relevance.

\section{Keywords}

Bahia $•$ Crisis of the Ancient Regime • Politic History.

\footnotetext{
${ }^{1}$ Doutoranda no Programa de Pós-Graduação em História Social - FFLCH/USP e Bolsista SAEB/ UESB.
} 
Em 22 de janeiro de 1808 atracaram nos portos da Bahia as embarcações que conduziam o príncipe regente d. João e parte da família real ao Rio de Janeiro. Era a primeira vez que um monarca europeu pisava em terras americanas após mais de três séculos de domínio colonial. Reconstituir toda a movimentação e os sentimentos dos habitantes diante de um acontecimento tão inusitado é algo que escapa ao historiador. No entanto, é possível examinar a dimensão que a transferência da Coroa bragantina provocou no reordenamento da capitania procurando articulá-la às transformações políticas mais gerais ocorridas no cenário mundial e na América em particular. ${ }^{2}$ De maneira mais específica, o artigo enfoca a situação da Bahia nesse cenário de crise atentando para as profundas mudanças verificadas a partir do estabelecimento do príncipe na nova sede da monarquia cuja elevação do Brasil à condição de Reino, em 1815, fora uma das decorrências mais significativas.

A historiografia sobre as independências das Américas hispânica e lusitana já destacou a importância do contexto mais amplo de fins do século XVIII, sobretudo após 1789, para a compreensão dos movimentos nas áreas coloniais que alteraram os pilares do Antigo Regime nessas áreas. As múltiplas mediações e experiências políticas vivenciadas pelas populações luso-espanholas fornecem um dos traços marcantes dos acontecimentos no período evidenciando a intensidade das alterações políticas e configurando uma dinâmica político-social que reitera a complexidade das circunstâncias de emergência dos Estados independentes e do sentimento nacional no Oitocentos. A extensão dessas alterações resultou de um mesmo processo de desestrutura dos absolutismos ibéricos possibilitando, no entanto, reações diversas entre as populações americanas a partir das suas próprias experiências políticas e em função das alternativas possíveis de superação da crise. ${ }^{3}$

\footnotetext{
${ }_{2}^{2}$ Para uma ampla análise das transformações no período, ver: HOBSBAWM, Eric J. A era das revoluções. $9^{\mathrm{a}}$. Ed. Rio de Janeiro: Paz e Terra, 1994; RÉMOND, René. O século XIX (1815-1914). São Paulo: Cultrix, 1976; GODECHOT, Jaques. Europa e América no tempo de Napoleão (18001815). São Paulo: Pioneira; Edusp, 1984. A sucessão dos acontecimentos pode ser acompanhada em JANCSÓ, István (Orient.). Cronologia de História do Brasil Monárquico, 1808-1889. São Paulo: Humanitas-FFLCH/USP, 2000.

${ }^{3}$ Sobre a crise do Antigo Regime na Europa e sua repercussão na América luso-espanhola, entre outros: FONTANA, Josep. La crisis del Antiguo régimen, 1808-1833. 2ª . Ed. Barcelona: Editorial Crítica, 1982; HALPERIN DONGHI, T. História da América Latina. $3^{\mathrm{a}}$. Ed. Rio de Janeiro: Paz e Terra, 1975; JANCSÓ, István. A construção dos Estados nacionais na América Latina. Apontamentos para o estudo do Império como projeto. In: SZMRECSÁNYI, Tamás; LAPA, José Roberto do Amaral (Orgs.). História econômica da Independência e do Império. São Paulo: Hucitec, 1996,
} 
De fato, as pressões exercidas por Napoleão Bonaparte para ampliar o seu domínio no continente europeu atingiram frontalmente a estabilidade política das monarquias ibéricas. Na Espanha, a transferência da Coroa dos Bourbons para José Bonaparte, irmão de Napoleão, em virtude das abdicações de Fernando VII e Carlos IV, em maio de 1808, resultou no rompimento do princípio da legitimidade dinástica ante o fortalecimento dos poderes regionais que acirraram os conflitos internos nas colônias hispânicas. Em Portugal, meses antes, o príncipe regente d. João, diante das ameaças de invasão do Reino português pelo exército napoleônico, viu-se obrigado a quebrar a política de neutralidade que havia mantido no conflito europeu e se transferiu para a colônia americana, provocando intensas mudanças para os portugueses dos dois lados do atlântico.

A correspondência mantida entre os ministros da Coroa e o governador da Bahia, d. Fernando José de Portugal, mostra que, desde fins do século anterior, existia uma preocupação crescente com a presença de navios franceses que rondavam a costa da capitania, assim como a falta de recursos disponíveis para a manutenção da sua defesa. Em 29 de agosto de 1796, o governador relatava as precárias condições de segurança diante das suspeitas de embarcações inimigas:

Sem embargo de me achar bastantemente [sic] falto de munições de guerra, como constantes vezes tenho representado por essa Secretaria de Estado, mandei aquele socorro, que me foi possível, de pólvora, bala e armamento para a capitania do Espírito Santo, para Porto Seguro, para os Ilhéus e para outras partes, [...] mas me não é possível dar a providência mais própria e oportuna para afugentar estes inimigos da Costa do Brasil [...], e por em mais algum sossego o comércio desta Capitania que está bastantemente [sic] perturbado com estes fatos bem notórios por não haver nestes portos embarcações de guerra que saíssem de guarda-costas quando a ocasião assim o pedisse. [...] Quem é responsável pela defesa de uma capitania tão importante como esta deve expor continuamente o estado em que se acha de defesa [...]. ${ }^{4}$

p. 3-26; PIMENTA, João Paulo Garrido. Estado e nação no fim dos impérios ibéricos no Prata (1808-1828). São Paulo: Hucitec/Fapesp, 2002; ARTOLA, Miguel. Antiguo Régimen y Revolucion liberal. Madrid: s. 1., 1979.

${ }^{4}$ Citado por SILVA, Ignácio Accioli de Cerqueira e. Memórias históricas e políticas da província da Bahia (anotadas por Braz do Amaral). Bahia: Imprensa Oficial do Estado, 1931, v. III, p. 194. 
Adiante reiterava a penúria dos armazéns reais pela falta de pólvora e de outras peças de artilharia, arrematando: "porém, como ninguém conhece melhor que V. Exa. o estado atual da Europa e as circunstâncias em que nos achamos com a França, não devo fazer mais ponderação alguma sobre esta matéria”. Dois anos depois, d. Rodrigo de Sousa Coutinho, ministro e secretário de Estado da Marinha e Domínios Ultramarinos, informava que a rainha, "sempre pronta a beneficiar e premiar os seus vassalos quando neles reconhece merecimento e virtudes", pretendia condecorar todos que se empenhassem na expulsão dos invasores e recomendava "a mais exata e escrupulosa vigilância" a um possível desembarque de uma fragata francesa. ${ }^{5}$

Curioso é que pouco tempo antes dos conflitos entre a França e Portugal se acirrarem, atracou no porto de Salvador, em 2 de abril de 1806, uma esquadra francesa sob o comando de Jerônimo Bonaparte, irmão de Napoleão, que retornava de uma tentativa frustrada de ocupação da ilha de Santa Helena e necessitava de reparos nas embarcações, víveres e tratamento para os tripulantes doentes. Governando a Bahia nesse período, o $6^{\circ}$ conde da Ponte, d. João de Saldanha da Gama Mello e Torres (1805-1809), encaminhou a d. João um relatório circunstanciado do seu contato com os comandantes da esquadra, esclarecendo sobre a maneira hospitaleira como os recebeu, além de intermediar um empréstimo com alguns negociantes para a aquisição dos gêneros que necessitavam. Agia, portanto, de maneira hábil. ${ }^{6}$

Em fins de 1807 Napoleão Bonaparte exigiu de Portugal uma tomada de posição diante dos conflitos na Europa depois de ter estabelecido um tratado com a Espanha. No ano anterior o general francês havia decretado o bloqueio continental proibindo qualquer intercâmbio comercial com a Grã-Bretanha. A situação não era das mais favoráveis para a Coroa portuguesa que decidiu abandonar o reino sob a proteção de uma escolta naval inglesa. Antes dessa decisão, porém, e ignorando a reação da Coroa britânica, o conde da Ponte havia sido avisado, em 7 de outubro, para impedir a saída de navios portugueses da capitania, tendo em vista que "apesar dos esforços e dos sacrifícios que o

\footnotetext{
${ }^{5}$ Idem, p. 190 e 191.

${ }^{6}$ Accioli informa que os negociantes Manoel José de Mello, Antônio da Silva Lisboa, Francisco Dias Coelho, José Domingues e José da Silva Ribeiro forneceram uma quantia de 24:000\$000 para os comandantes. Op. cit., p. 37. Sobre a presença das esquadras francesas na costa da Bahia, ver: TAVARES, Luis Henrique Dias. História da Bahia. $10^{\mathrm{a}}$. Ed. São Paulo: Editora UNESP; Salvador: EDUFBa, 2001.
} 
Príncipe Regente” havia feito para manter uma política de neutralidade, “[...] as circunstâncias políticas atuais da Europa são tais que é muito para recear que Portugal se ache muito brevemente obrigado a fechar os seus Portos do Continente desta parte do Mundo aos Ingleses, para evitar uma invasão de Tropas Francesas superiores neste Reino". 7 Decidindo pela aliança com a Grã-Bretanha e se abrigando em sua colônia mais proeminente, o príncipe tentava evitar um destino semelhante aos dos soberanos da Espanha.

Embora a preparação para a travessia do atlântico em direção ao Rio de Janeiro tenha sido feita às pressas - cerca de quinze embarcações transportando um enorme contingente de pessoas entre membros da família real, nobres e funcionários régios -, o projeto de o monarca residir na América não era recente, pois, desde pelo menos a união das Coroas de Espanha e de Portugal sob Filipe II (1580-1640), a medida havia sido cogitada em caso de situações críticas que colocassem em risco a estabilidade da monarquia. Posteriormente essa perspectiva seria recuperada por agentes ilustrados, cuja imagem de grandeza do Novo Mundo como uma alternativa nas circunstâncias de crise extrema vivenciada pela monarquia portuguesa apareceria de maneira recorrente. ${ }^{8}$ Uma carta dirigida ao príncipe regente, em 30 de maio de 1801, pelo marquês de Alorna, d. Pedro de Almeida Portugal, alertandoo sobre o agravamento da situação política da Europa, exemplifica essa retomada da possibilidade de mudança da corte para a colônia americana:

V.A.R. tem um grande império no Brasil, e o mesmo inimigo que ataca agora com tanta vantagem, talvez que trema, e mude de projeto, se V.A.R. o ameaçar de que se dispõe a ser imperador naquele vasto território adonde pode facilmente conquistar as colônias espanholas e aterrar em pouco tempo as de todas as potências da Europa. Portanto é preciso que V.A.R. mande armar com toda a pressa os seus navios de guerra, e todos os de transporte, que se acharem na praça de Lisboa-que meta neles a princesa, os seus filhos, e os seus tesouros, e que ponha tudo isso pronto a partir

\footnotetext{
${ }^{7}$ APEB. Seção de Arquivo Colonial e Provincial. Ordens Régias. Maço: 103 (1807-1808).

${ }^{8}$ De acordo com Maria de Lourdes Viana Lyra, a fala dos agentes ilustrados retoma a concepção do "Quinto Império", elaborada pelo Padre Antônio Vieira no século XVII no contexto do domínio espanhol, no sentido de reforçar a potencialidade do Brasil para o fortalecimento do Reino de Portugal. Cf. A utopia do poderoso Império. Portugal e Brasil: Bastidores da política, 1798-1822. Rio de Janeiro: Sette Letras, 1994, p. 121-124.
} 
sobre a barra de Lisboa, e que a pessoa de V.A.R. venha a esta fronteira da Beira, aparecer aos seus povos, e acender o seu entusiasmo $\left[\ldots . .{ }^{9}\right.$

Mais tarde foi a vez de d. Rodrigo de Sousa Coutinho expor as razões pelas quais considerava necessária a mudança da corte. Segundo ele: “[...] Quaisquer que sejam os perigos, que acompanhem uma tão nobre, e resoluta determinação, os mesmos são sempre muito inferiores aos que certamente hão de se seguir da entrada dos Franceses nos Portos do reino e que ou hão de trazer a abdicação de V.A.R. à sua real Coroa, a abolição da Monarquia ou uma opressão fatal [...]". ${ }^{10}$ O agravamento das turbulências políticas no limiar do Oitocentos evidenciou que o Reino português não se encontrava em condições de confrontar a França napoleônica tornando inadiável a proposição de retirada da família real da Europa. ${ }^{11}$

A viagem, iniciada em 29 de novembro, teve algumas turbulências climáticas resultando no desvio de parte da frota portuguesa para a Bahia. Quase dois meses depois as embarcações atracavam no porto de Salvador conduzindo em uma delas o príncipe regente. ${ }^{12}$ Já alertado sobre essa possibilidade, ${ }^{13}$ o governador intensificou as determinações para as autoridades locais visando atender as necessidades que a ocasião exigia: iluminação da cidade, Te Deum, beija-mão,

\footnotetext{
${ }^{9}$ Citado por ARRUDA, José Jobson de Andrade. Uma colonia entre dois Impérios. A abertura dos portos brasileiros, 1800-1808. São Paulo: Edusc, 2008, p. 147-148. O documento encontra-se também transcrito em NORTON, Luís. A corte de Portugal no Brasil. $2^{a}$. Ed. São Paulo: Companhia Editora Nacional; Brasília: INL, 1979, p. 1.

${ }^{10}$ Citado por ARRUDA, José Jobson de Andrade, op. cit., p. 149.

${ }^{11}$ Para Oliveira Lima, longe de ser vista como uma deserção covarde, a trasladação da corte para o Rio de Janeiro deve ser considerada "uma inteligente e feliz manobra política". Cf. D. João VI no Brasil. 3. Ed. Rio de Janeiro: Topbooks, 1996, p. 43. Questão que ainda divide historiadores. Folha de São Paulo. Caderno Mais, São Paulo, 25 de novembro de 2007.

${ }^{12}$ A divisão da frota preocupou os ministros de d. João. Em 5 de fevereiro de 1808, o Visconde de Anadia enviou ofício ao conde da Ponte informando sobre a possibilidade de a embarcação do príncipe ancorar na Bahia, solicitando informações sobre o assunto. Arquivo Público do Estado da Bahia (APEB). Seção de Arquivo Colonial e Provincial. Ordens Régias. Maço: 108 (1807-1810). A esquadra portuguesa era composta de três naus, uma fragata e um bergantim. Cf. TAVARES, Luís Henrique Dias, op. cit., p. 209.

${ }^{13} \mathrm{O}$ conde da Ponte teria sido avisado da partida da família real de Lisboa pela tripulação de um navio mercante baiano e após ter recebido a cópia do decreto de 26 de novembro de 1807 no qual o regente justificava a resolução de transferir-se para o Brasil. Em função disso, expedira ordens ao Coronel do Regimento de Milícias da Torre determinando "ordenar aos portos do mar de seu distrito, no sentido de os pescadores, jangadeiros e soldados dos referidos postos manterem toda vigilância para que o governo fosse com antecedência avisado da aproximação da frota, no caso de vir aqui arribar". Citado por PINHO, Wanderley. A abertura dos portos. Cairu. Os Ingleses. A Independência. Salvador: Publicações da Universidade da Bahia, 1961, p. 49.
} 
além das acomodações e alimentação necessárias para os visitantes. A capitania, quase meio século depois de ter perdido a sede de Vice-Reino para o Rio de Janeiro (1763) era a primeira a receber o príncipe e parte do seu séqüito. ${ }^{14}$

Para alguns residentes, a situação incomum exigia demonstrações de submissão e contentamento, mas também propiciava o encaminhamento das suas aspirações. As diversas petições entregues a d. João sinalizam que as classes proprietárias da cidade de Salvador depositavam extrema confiança nas possibilidades políticas e econômicas que a sua presença na América poderia proporcionar. Era preciso expressar o reconhecimento pela decisão do príncipe de residir na colônia e, ao mesmo tempo, afirmar a importância da capitania na preservação dos interesses da Coroa.

Ao chegar a Salvador, em 22 de janeiro de 1808, d. João encontrou uma cidade bastante movimentada. Segundo uma correspondência do conde da Ponte no ano anterior, o último alistamento feito indicava " 25.502 pretos quando o número de brancos não excede a 14.260 e o de pardos a 11.350", totalizando, portanto, 51.112 habitantes. ${ }^{15}$ Outros dados afirmam que em fins do século XVIII a capital possuía, junto com o Recôncavo, cerca de 150 mil habitantes, cuja maioria era constituída por negros e afro-mestiços. ${ }^{16}$ Por mais de dois séculos Salvador havia ocupado a sede de Vice-reino e a Bahia se tornara uma das principais possessões do Império português. Mesmo após a transferência da capital para o Rio de Janeiro em 1763, a cidade permaneceu usufruindo a posição de centro administrativo de toda a capitania. Inúmeros navios e embarcações pequenas circulavam pelos seus portos impulsionando um intenso comércio local, de exportação e importação, além de um dos mais poderosos mercados

\footnotetext{
${ }^{14}$ Wanderley Pinho registra ofício enviado pelo conde da Ponte às autoridades das vilas do Recôncavo solicitando a remessa de farinhas, legumes de grão (milho, feijão e arroz), gêneros comestíveis, galinhas, frangos, patos, leitões e capados. Em outra correspondência para as vilas de São Francisco, Santo Amaro e Cachoeira requer 60 bois "de seus engenhos e outros de seu distrito". Op. cit., p. 49 e 51. Entre os acompanhantes do príncipe, encontrava-se d. Fernando José de Portugal, o futuro marquês de Aguiar, que havia governado a Bahia no período de 18 de abril de 1788 a 23 de setembro de 1801.

${ }^{15}$ Ofício do conde da Ponte para o Visconde de Anadia, em 16 de julho de 1807, publicado por Braz do Amaral em Ignácio Accioli, op. cit., v. III, p. 228.

${ }^{16}$ BARICKMAN, Bert J.. Um contraponto baiano. Açúcar, fumo, mandioca e escravidão no Recôncavo, 1780-1860. Rio de Janeiro: Civilização Brasileira, 2003, p. 45. O autor chama a atenção para a imprecisão dos dados disponíveis sobre a população da Bahia no período. Conforme esclarece, os habitantes negros e afro-mestiços eram constituídos por "escravos alforriados, os descendentes ingênuos (i.e. nascidos livres) de escravos libertos e grande número de homens e mulheres cativos". Loc. cit.
} 
de escravos do mundo colonial, fazendo da urbe e do seu hinterland uma das mais dinâmicas para os padrões do período. Por esses lugares circulavam numerosas pessoas - escravos, libertos e homens livres - que forneciam à cidade as características de um dos principais centros do novo mundo. ${ }^{17}$

Uma das primeiras representações encaminhada ao príncipe pelo corpo do comércio manifestava o desejo que a cidade abrigasse a sede da corte. Para os peticionários, razões estratégicas que possibilitariam as condições necessárias para a defesa do trono português e, sobretudo, para a ampliação da riqueza do Império eram fartas:

A sua elevada posição parece ter sido desenhada pela natureza com o destino de aí erigir o trono do maior dos Soberanos. [...] Vastas matarias ao sul estão convidando aos povos a administrar a variedade das suas grossas, e pesadas madeiras, atraindo-os ao trabalho de fabricar tão respeitável marinha que segure não só a estabilidade do trono Lusitano, mas uma superioridade que ganhe respeito e admiração das nações que habitam na Europa. O seu incomparável porto, o mais belo do mundo, está como no centro das colônias de V.A. que dominando a África, lhe abre uma comunicação tanto mais fácil e breve com a Ásia, como com as nações aliadas da Europa, quanto fica sendo o seu comércio mais ativo, na reprodução dos variados ramos da sua agricultura. ${ }^{18}$

A descrição das potencialidades da capitania, no entanto, não foi suficiente para demover o príncipe regente da decisão tomada no ano anterior de residir no Rio de Janeiro. Uma das razões para isso teria sido a pouca segurança em função da sua localização em uma ampla baía que a deixava extremamente exposta a ataques externos. ${ }^{19}$ Todavia, outras solicitações não foram negadas, dentre as quais, a condecoração de membros do senado da câmara e de indiví-

\footnotetext{
${ }^{17}$ MATTOSO, Kátia M. de Queirós. Bahia século XIX: uma província no Império. $2^{\mathrm{a}}$. Ed. Rio de Janeiro: Nova Fronteira, 1992. Sobre a importância político-administrativa da cidade de Salvador, ver ainda: RUY, Affonso. História da Câmara Municipal de Salvador. Salvador: Câmara Municipal, 1953. SOUZA, Avanete Pereira. Poder político local e cotidiano: a Câmara de Salvador no século XVIII. Dissertação (Mestrado em História). Universidade Federal da Bahia, Salvador, 1996.

${ }^{18}$ Citado por SILVA, Ignácio Accioli de Cerqueira e, op. cit., p. 231-232.

${ }^{19} \mathrm{Idem}$, p. 48. O padre Perereca (Luiz Gonçalves dos Santos), panegirista de d. João, dimensiona o lamento dos baianos com a partida do príncipe para o Rio de Janeiro em 26 de fevereiro. SANTOS, Luis Gonçalves dos. Memórias para servir à História do Reino do Brasil. Belo Horizonte: Itatiaia; São Paulo: Edusp, 1981, p. 171.
} 
duos pertencentes à "nobreza" da cidade; a criação da escola de cirurgia, uma fábrica de vidros e a implantação da primeira companhia de seguros, a pedido dos negociantes locais.

Mas, certamente, a decisão de maior alcance tomada poucos dias depois da sua chegada à Bahia, em 28 de janeiro, foi a assinatura da carta régia que autorizou a abertura dos portos do Brasil às nações amigas, eliminando o domínio exclusivo exercido pelo comércio português na colônia. A capitania vivenciava uma situação difícil em virtude da determinação para impedir a saída de navios do porto de Salvador, em outubro do ano anterior, por conta do agravamento da crise política na Europa. Na representação entregue ao príncipe, um dia antes do decreto-régio, o governador descreveu os abalos causados à economia local e, "em nome do Comércio, da Lavoura e benefício de todos estes habitantes, e a bem dos Rendimentos Reais", requereu a suspensão do embargo sobre a circulação livre de navios: "fazendo-se público na Praça comerciante que são nossos Inimigos França e Espanha e nossa aliada a Grã-Bretanha e que debaixo dessa hipótese se permita navegar livremente para Portos que ou as notícias públicas ou as particulares de seus correspondentes lhes indiquem mais vantajosas às suas especulações". ${ }^{20}$

Até que ponto o economista, José da Silva Lisboa, natural da Bahia e então Secretário da Mesa de Inspeção em Salvador, fora o responsável para a elaboração da medida é uma questão ainda dissonante. De qualquer maneira, é inconteste que a defesa que fazia das doutrinas liberais, além do profundo conhecimento sobre a situação econômica colonial, causaram grande impressão no príncipe a ponto de criar uma cadeira de Economia Política no Rio de Janeiro para que assumisse como professor em razão de ter "dado provas de ser muito hábil pra o ensino daquela ciência, sem a qual se caminha às cegas e com passos mui lentos, e às vezes contrários nas matérias de governo". ${ }^{21}$ Mais uma vez é

\footnotetext{
${ }^{20}$ A cópia da representação encontra-se transcrita em PINHO, Wanderley, op. cit., p. 55-56.

${ }^{21}$ Conforme os termos do decreto régio (disponível no site: www.câmara.gov.br). Alguns autores, embora possuam diferenças sobre a atuação do futuro visconde de Cairu nesse contexto, não desprezam a sua importância. Entre os que dão maior destaque a sua participação para a abertura dos portos, encontram-se Pinto de Aguiar (A abertura dos portos do portos do Brasil. Cairu e os ingleses. Livraria Progresso Editora. Edição conjunta com a Câmara Municipal da cidade do Salvador, 1960) e Wanderley Pinho (op. cit.). José Jobson de Andrade Arruda (op. cit.) sublinha a sua importância, mas não o considera como o responsável pela medida. Antônio Penalves Rocha ressalta o significado de José da Silva Lisboa para a difusão da Economia Política do Brasil na qual o seu estudo Princípios de Economia Política ocupa lugar importante e investiga o processo de elaboração das suas concepções nesse campo. Cf. A economia política na sociedade escravista.
} 
sintomática a criação dessa "aula" de economia, antes mesmo da existência de um curso semelhante em Portugal, denotando o esforço do governo de d. João em agregar funcionários régios preparados nos seus quadros administrativos num período especialmente crítico para a monarquia portuguesa. ${ }^{22}$

Para Silva Lisboa, a abertura dos portos era inevitável diante da impossibilidade de subsistência do antigo sistema colonial e ele não tinha dúvidas quanto à autoria desse feito: "O Senhor D. João resolveu o fazer tanto bem sem esperar pelos conselheiros de Estado, que se tinham desvairado em rumo, pela dispersão da tempestade na costa de Portugal. É, pois, inteiramente obra sua a carta régia, foral novo do Brazil [...]". ${ }^{23}$ Segundo afirma, a medida possuía uma importância não apenas no campo econômico ao facultar a implantação do livre-comércio, mas também político-social, tendo em vista que poderia possibilitar a "conciliação de classes" ou de "interesses" entre aqueles que integravam o amplo e complexo econômico português. A Coroa, desse modo, dava os primeiros passos para garantir a estabilidade do Império naquela conjuntura correspondendo aos anseios daqueles que defendiam um sistema econômico sustentado em alguns princípios liberais, mesmo que não vissem nenhuma incompatibilidade nessa adoção com a manutenção da monarquia, como era o caso do próprio José da Silva Lisboa. ${ }^{24}$

Meses antes, em 20 de maio de 1807, o conde da Ponte, a pedido do príncipe regente, encaminhara algumas questões ao Senado da Câmara de Salvador referentes aos problemas presentes e as perspectivas vantajosas para a lavoura e o comércio da capitania. $\mathrm{O}$ conselho, então, solicitou a quatro proprietários que dessem seu parecer sobre o assunto. O resultado é uma exposição importante sobre os empecilhos que se apresentavam para os proprietários locais naquele início do Oitocentos e as intervenções necessárias para que pudessem fazer melhor uso de seus investimentos favorecendo o desenvolvimento do comércio e da agricultura. Entre os signatários, sobressai a posição de João Rodrigues de Brito, que viria a ocupar o cargo de desembargador da Relação da Bahia, pela agudeza das suas observações denotando estreita vinculação com as idéias

São Paulo: Hucitec/USP, 1996a.

${ }^{22}$ Cf. ROCHA, Antônio Penalves, op. cit., p. 36.

${ }^{23}$ LISBOA, José da Silva. Memórias dos beneficios políticos do governo de El Rey Nosso Senhor D. João VI. $2^{\text {a }}$. Ed. Rio de Janeiro, 1940, p. 68 (grifos do autor).

${ }^{24}$ ROCHA, Antônio Penalves, op. cit., p. 105 e Economia política e política no período joanino. In: SZMRECÁNYI, Tamás; LAPA, José Roberto do Amaral (Orgs.), op. cit., 1996b, p. 31. O autor discute as bases de formação do pensamento econômico de Silva Lisboa. 
liberais econômicas correntes na Europa nesse momento. Conforme observa, dentre as diversas causas responsáveis pelos males da lavoura, indicaria apenas as principais: Liberdades, Facilidades e Instruções.

[...] falando primeiro das que nascem da falta de LIBERDADE nos Lavradores, para empregarem seus braços e capitais da maneira que julgam mais conveniente. Em segundo lugar das que vem da falta das FACILIDADES próprias para auxiliar o exercício daquela LIBERDADE, como estradas, pontes, e outras obras, e instituições, que diminuindo as despesas, e obstáculos das comunicações e transportes, aumentam em conseqüência os reditos da Lavoura. Em terceiro e último lugar das que resultam da falta das INSTRUÇÕES necessárias aos Lavradores para se aproveitarem daquelas LIBERDADES, e FACILIDADES. ${ }^{25}$

Mesmo considerando diferentes posicionamentos sobre as questões entre os autores do documento, ${ }^{26}$ a mobilização desses indivíduos para proporem mudanças no âmbito do universo econômico do Império português pode, a princípio, parecer um contra-senso haja vista que o pensamento crítico sobre o comércio metropolitano poderia expor as próprias mazelas do sistema. No entanto, esse recurso parece ter sido uma tática importante na costura das alianças entre a Coroa e os proprietários locais num momento em que as bases de sustentação do absolutismo monárquico enfrentavam severas críticas. ${ }^{27}$ É nesse sentido que se pode avaliar a importância da abertura dos portos.

Embora se argumente que o comércio feito de maneira ilícita de há muito rompia com as amarras do sistema colonial e que, portanto, o documento apenas reconheceria uma prática corriqueira, ${ }^{28}$ a decisão, efetivamente, integrou o processo de reordenamento do quadro econômico da monarquia lusa como um recurso importante para salvaguardar os seus interesses em uma conjuntura

\footnotetext{
${ }^{25}$ BRITO, João Rodrigues de et al. Cartas econômico-politicas sobre agricultura e comércio da Bahia. Lisboa: Imprensa Nacional, 1821, p. 27-28.

${ }^{26}$ Frederic Morton observa que João Rodrigues de Brito e Joaquim Ignácio de Siqueira Bulcão, outro proprietário que respondera as questões, possuíam diferentes concepções sobre o papel do Estado na economia. Cf. MORTON, F.W.O.. The Conservative Revolution of Independence: Economy, society and politics in Bahia (1790-1840). University of Oxford, 1974, p. 111.

${ }^{27}$ Sobre as contradições inerentes ao sistema colonial dentre os quais a mobilização do pensamento crítico, ver o clássico estudo de NOVAIS, Fernando A.. Portugal e Brasil na crise do Antigo Sistema Colonial (1777-1808). São Paulo: Hucitec, 1983.

${ }^{28}$ PINHO, Wanderley, op. cit.
} 
bastante adversa. Afinal de contas, em virtude do bloqueio continental decretado por Bonaparte e da invasão de Portugal, os principais portos portugueses estavam sob o controle da França impedindo que intermediassem o comércio entre as possessões portuguesas e a Europa. Era preciso garantir a continuidade das conexões entre a Coroa e os mercados europeus. ${ }^{29}$ Ademais, não se pode perder de vista o significado político da medida tanto no quadro de redefinição do Império português quanto para os habitantes da América portuguesa. E, nesse caso, não apenas pela perspectiva de novas rotas de comércio.

O que chama a atenção nesse momento é que se por um lado a abertura dos portos ao comércio exterior reposicionava o lugar ocupado pela possessão americana nos quadros econômicos do período ao permitir que dispusesse de novas condições comerciais; por outro, punha em evidência uma inquietação para parte da classe proprietária da Bahia, qual seja, a possibilidade de ampliação no número de comerciantes estrangeiros, particularmente da Inglaterra, em Salvador. É o que expressa uma das representações entregues ao príncipe antes de sua viagem para o Rio de Janeiro:

[...] Que coisa mais justa, Senhor, do que V.A.R. que é o pai da pátria e que olha, como agora ternamente experimentamos, para o seu povo como para a sua numerosa família, que vem humilde congratular-se aos seus pés, beijar-lhe a mão augusta, buscar o refúgio da sua beneficiência, abrir uma porta franca à felicidade dos comerciantes nacionais, não permitindo que se estabeleçam estrangeiros com casas de negócio nos domínios do Brasil, mas sim mandar que sejam tratados com os ofícios da hospitalidade nas ocasiões necessárias e oportunas, e que se pratique com todos igualmente o Direito das Gentes, sem aquela singularidade que vai constituir o prejuízo dos mesmos negociantes $\left[\ldots . .{ }^{30}\right.$

O documento sinaliza, portanto, uma questão de singular importância nesse novo contexto: o deslocamento de um dos eixos do debate político que, a partir desse momento, deixava de ser um confronto entre os defensores do exclusivo e os do livre-comércio para se restringir entre os partidários do livre-comércio e

\footnotetext{
${ }^{29}$ Cf. ROCHA, Antônio Penalves, op. cit., 1996a, p. 104-105. Sobre o contrabando: PINHO, Wanderley, op. cit.; ARRUDA, José Jobson de, op. cit.

${ }^{30}$ Citado por SILVA, Maria Beatriz Nizza da. A primeira gazeta da Bahia: Idade d'Ouro do Brazil. $2^{\text {a }}$. Ed. revista e ampliada. Salvador: EDUFBa, 2005, p. 150-151.
} 
os do protecionismo. Reiterando ainda que outros elementos postos pelas novas condições, de abertura dos portos e domínio dos ingleses, exigiam "redefinição do papel do Estado no tocante à vida econômica, ou mais claramente, apontando para alguns dos impasses criados pela abertura dos portos e a concomitante supremacia inglesa". ${ }^{31}$ Esse é um elemento importante, pois a sua resolução não apenas atingia os interesses de ingleses e portugueses europeus como também os dos portugueses americanos que a partir da trasladação da Coroa viram abertas amplas perspectivas para sua ascensão. Além disso, indica que entre os proprietários existiam profundas divergências sobre o grau de intervenção a ser desempenhado pelo Estado na vida econômica, como bem o demonstra Felisberto Caldeira Brant Pontes, senhor de engenho e inspetor geral das tropas da Bahia, anos mais tarde numa carta enviada a José da Silva Lisboa:

Os invejosos e ignorantes na falta de boas razões para combater os sólidos princípios de economia política com que V.S. de longos anos procura felicitar a Nação têm constantemente recorrido ao exemplo de Inglaterra, que apesar de ser a Pátria de Smith nunca adotou o sistema liberal, mas não sei que dirão agora à vista da famosa petição dos negociantes ingleses apresentada ao Parlamento contra todos esses chamados favores a benefício da indústria nacional. ${ }^{32}$

E complementava: "Estava a ponto de copiar a petição para mandar a V.S. quando recebi a terceira parte dos Estudos do Bem Comum, pela qual vejo que V.S. já tinha conhecimento da dita petição", evidenciando o quanto esses homens estavam informados sobre as alterações liberais em curso no Ocidente nas primeiras décadas dos anos 1820 .

A rigor, a transferência da família real para a América resultou em mudanças significativas para os habitantes do Império português e, em especial, para os portugueses americanos e não apenas para os residentes do Rio de Janeiro, então sede da monarquia, e das áreas no seu entorno. Para o caso da Bahia, é possível avaliar como a partir de 1808 se instala uma intensa articulação entre o governo local, a corte e parte da sua população que, de diversas maneiras, buscaram

\footnotetext{
${ }^{31}$ JANCSÓ, István e PIMENTA, João Paulo G.. Peças de mosaico (ou apontamentos para o estudo da emergência da identidade nacional brasileira). In: MOTA, Carlos Guilherme (Org.). Viagem Incompleta. A experiência brasileira (1500-2000). Formação: histórias. São Paulo: Senac, 2000, p. 152-153.

${ }^{32}$ Ministério da Justiça. Arquivo Nacional. Economia açucareira da Bahia em 1820. Cartas de Felisberto Caldeira Brant Pontes, marquês de Barbacena. Publicação destinada ao III Congresso de História da Bahia, junho de 1973. A carta para José da Silva Lisboa data de 2 de outubro de 1820.
} 
usufruir as novas condições propiciadas nesse período. Os documentos são fartos no registro de variadas intervenções que dão conta dessa movimentação interna e possibilita maior visibilidade ao lugar ocupado pela Bahia no conjunto das possessões da Coroa bragantina.

\section{Crise e administração política}

Um dos aspectos importantes desse período dizia respeito certamente à segurança da capitania, "principalmente nas circunstâncias tão críticas em que se acha a Europa" e a fixação da família real na América portuguesa. Ainda em solo baiano, o príncipe autorizou a criação de uma fábrica de pólvora, uma fundição para refundir peças fora de uso, a ampliação dos regimentos de infantaria e de cavalaria e a abertura de estradas especialmente para o Rio de Janeiro, além de instituir uma Junta de Defesa para auxiliar o governador nas reformas militares necessárias. ${ }^{33}$

De fato, o quadro de incertezas no cenário europeu exigia que a montagem do aparato de defesa das capitanias, sobretudo àquelas que ocupavam uma posição extremamente estratégica e, portanto, aguçavam a cobiça das nações rivais, como era o caso da Bahia, fosse condizente com as novas circunstâncias. As inúmeras medidas referentes às inovações militares indicam uma crescente preocupação em dotá-la dos requisitos necessários a uma estrutura de defesa eficiente. Isso fica ainda mais evidenciado na ordem régia enviada ao conde da Ponte, em 24 de março de 1808, portanto, pouco tempo depois da instalação do príncipe na corte, na qual se requer informações minuciosas sobre a situação de defesa da Bahia (população, regimentos, portos, despesas com o exército, pólvora, etc), tendo em vista a criação de "uma nova Repartição de Guerra de todo o seu principado do Brasil, prontamente com a Repartição dos Negócios Estrangeiros". ${ }^{34}$ Não se pode esquecer que em $1^{\circ}$. de maio desse ano a Coroa portuguesa declarou guerra à França, agravando ainda mais as relações políticas entre ambas. ${ }^{35}$ A política externa da corte iria mais além. As tensões entre França

\footnotetext{
${ }^{33}$ SILVA, Ignácio Accioli de Cerqueira e, op. cit., p. 51; KRAAY, Hendrik. Race, State and Armed Forces in Independence-era Brazil. Bahia, 1790s-1840s. Stanford: Stanford University Press, 2001, p. 31.

${ }^{34}$ APEB. Seção de Arquivo Colonial e Provincial. Ordens Régias. Maço: 106 (1808-1809).

${ }^{35}$ Em correspondência ao governo da Bahia, datada de 14 de julho de 1808, a corte informa o envio de 200 exemplares do manifesto para divulgação na capitania. APEB. Seção de Arquivo Colonial e Provincial. Ordens Régias. Maço: 106 (1808-1809).
} 
e a Grã-Bretanha no plano europeu possuíam desdobramentos diretos no projeto de d. João de estender os seus domínios na América após a sua fixação no Rio de Janeiro, aprofundando, assim, os conflitos com a Espanha. A determinação para ocupar a Guiana Francesa (1809) e, mais especificamente, a Banda Oriental (1811), tornou ainda mais complexa a situação política no cenário de crise do Antigo Regime. Temendo represálias, a Coroa contraíra, inclusive, um empréstimo com o grande negociante da Bahia, Pedro Rodrigues Bandeira, no valor de 40 contos de réis, a juros de $5 \%$, para auxiliar na segurança da capitania. ${ }^{36}$

Ao que tudo indica, a mobilização nesse sentido não se dava apenas nas esferas do governo, mas também entre os indivíduos interessados na ocupação de cargos novos ou antigos. A proposta de criação de um corpo de cavalaria na Bahia, em 1809, pode ser citada como exemplo. Copiosas e extensas petições foram encaminhadas à corte do Rio de Janeiro detalhando as razões pelas quais os requerentes deveriam contar com o beneplácito do príncipe para ocupar os principais cargos dos 255 previstos para a nova corporação. ${ }^{37}$ José Maria de Gouveia Portugal pretendia seguir o exemplo do seu pai, coronel agregado do $1^{\circ}$. Regimento de Linha Pedro Alexandrino de Souza Portugal, "que consta 40 anos de serviço", do avô, brigadeiro Antônio José de Souza Portugal, "que contou no Real Serviço perto de sessenta e três anos até o dia da sua Reforma" e do bisavô "Manoel Domingues Portugal, coronel que foi do mesmo $1^{\circ}$. Regimento de Linha, em cujo posto faleceu com perto de 55 anos de Serviço".

Além disso, o requerente tencionava dar "prova de fidelidade", pois fora "um dos primeiros voluntários que se veio oferecer" quando o governador publicou um bando, "que em data de 20 de março de 1808 fazia conhecer aos seus habitantes a necessidade que havia de aumentar a tropa para a defesa dela [capitania]" ${ }^{38}$ Joaquim José dos Passos, capitão do terço das ordenanças da companhia da primeira divisão da Freguesia do Senhor do Bonfim da Matta da cidade da Bahia, desejava assumir o posto de sargento-mor e fundamentou o

\footnotetext{
${ }^{36}$ BANDEIRA, Luiz Alberto Moniz. O feudo. A casa da Torre de Garcia d'Ávila: da conquista dos Sertões à Independência do Brasil. Rio de Janeiro: Civilização Brasileira, 2000, p. 366. Sobre os conflitos na região do Rio do Prata no contexto de crise do Antigo Regime, ver PIMENTA, João Paulo Garrido, 2002, op. cit.

${ }^{37}$ Conforme plano detalhado incluso junto a um dos pedidos no qual consta, além da relação do armamento a ser utilizado, observações quanto ao fardamento e valores dos vencimentos em períodos de paz e de guerra. APEB. Seção de Arquivo Colonial e Provincial. Ordens Régias. Maço: 106 (1808-1809).

${ }^{38}$ Idem, ibidem.
} 
seu requerimento, em julho de 1809, alegando a dedicação com que havia servido há oito anos, efetuando prisões "de alguns facínoras, e até dos levantados negros à força de armas com considerável risco da sua vida e à custa da sua própria fazenda". Afirmava ter mandado "erguer uma igreja no sítio de Pirajá [...] que teve a honra de oferecê-la a Vossa Alteza Real na ocasião em que felizmente chegara à mesma cidade da Bahia" e, aproveitava a ocasião também para requerer a "Mercê do Hábito de São Bento de Aviz". ${ }^{39}$

Em outra circunstância, o inspetor do arsenal da marinha de Salvador, Bernardino José de Castro, reforçou o pedido de um suplicante para trabalhar no dito arsenal lembrando que na capitania "afirmativamente se pode dizer que há os melhores práticos de construções de navios", e que necessitava dos seus conhecimentos sobre madeiras. ${ }^{40} \mathrm{O}$ tempo de serviço dedicado à carreira militar constituía um dado importante na disputa por uma promoção pelo menos para as funções que exigiam menos conhecimento técnico e mais experiência na oficialidade, daí resulta as extensas justificativas dos serviços prestados à Coroa como no caso do aspirante ao posto de $1^{\circ}$ tenente da marinha, José Francisco de Oliveira, que servira nas tropas de linha da praça da Bahia " 25 anos, um mês e 12 dias". ${ }^{41}$

Para aqueles que, entretanto, não tinham opções de escolha, o ingresso nos quadros da nova estrutura militar se dava por caminhos bem mais tortuosos. Em 23 de novembro de 1808, o arsenal real da marinha do Rio de Janeiro requisitou "até cem" índios para os "grandes trabalhos" que deveriam realizar "apenas por um tempo de dois anos, no fim dos quais se revezarão por outros e tanto a vinda quanto a volta serão convenientemente vestidos por conta da Real Fazenda". ${ }^{42}$ Na mesma direção, a requisição de grumetes, feitas ao governo da Bahia pelo almirante general da marinha, em 14 de junho de 1809, procurava conciliar a falta de homens para o serviço militar com o enquadramento daqueles tidos por perniciosos ao Estado:

Carecendo-se muito de grumetes para o serviço da Marinha, e sendo

\footnotetext{
${ }^{39}$ Idem, ibidem.

${ }^{40}$ Idem, ibidem.

${ }^{41}$ Idem, ibidem. Para KRAAY, era por meio dos requerimentos que os oficiais reafirmavam a cumplicidade que os vinculava ao monarca. KRAAY, Hendrik. Race, State and Armed Forces in Independence-era Brazil. Bahia, 1790s-1840s. Stanford: Stanford University Press, p. 38. ${ }^{42}$ APEB. Seção de Arquivo Colonial e Provincial. Ordens Régias. Maço: 106 (1808-1809).
} 
mais do que provável que no vosso governo exista gente ociosa e vadia que perturbando ai o sossego público e a marcha do governo pode, aliás, servir a bordo e talvez se corrigir, com grande proveito do Estado, confio [...] que em todas as ocasiões possíveis, envieis recrutas dessa gente para o sobre mencionado serviço, as quais deverão ser entregues ao Inspetor de Arsenal desta cidade. ${ }^{43}$

Cerca de um mês depois, d. Rodrigo de Sousa Coutinho, então ocupando a Secretaria de Negócios Estrangeiros e da Guerra, reforçava as medidas necessárias para a segurança da capitania exigindo informações detalhadas sobre os meios de prevenção adotados "para segurar esse porto e cidade contra qualquer invasão ou surpresa de uma esquadra inimiga acompanhada de grandes forças de desembarque e que tudo aquilo que esse Governo interino, ouvindo os oficiais Engenheiros e Artilheiros, julgar necessário para conseguir este fim, principie logo a fazê-lo executar". ${ }^{4}$

Se as atenções da Coroa e do governo local estavam voltadas para os desdobramentos das guerras na Europa, não se pode dizer que, internamente, o clima era de total tranqüilidade. É bem verdade que após a sedição de 1798 , quando um grupo de militares, artesãos e escravos, reivindicaram os ideais de "liberdade, igualdade e fraternidade" para todos os bahienses, as possibilidades de contestação estavam ainda mais restritas. Afinal de contas, a violenta repressão que se abateu sobre os quatro líderes do movimento, enforcados e esquartejados na Praça da Piedade em Salvador, deixara explícita a intolerância da Coroa para comportamentos considerados perniciosos. Não obstante, era preciso manter a vigilância cerrada.

Como já se constatou, a Bahia possuía uma grande concentração de riqueza fruto de uma economia agroexportadora sustentada na mão-de-obra escrava, produzindo um enorme fosso entre a classe dominante - os senhores de engenho - e uma imensa massa de trabalhadores cativos utilizados principalmente nas grandes áreas produtoras que, por mais de trezentos anos, sustentaram a produção econômica da capitania, vinculando-a à economia mundial. Executores de numerosas ocupações, os trabalhadores escravos estavam amplamente disseminados na sociedade da época, da lavoura às cidades, dos grandes aos pequenos

\footnotetext{
${ }^{43}$ Idem, ibidem.

${ }^{44}$ SILVA, Ignácio Accioli de Cerqueira e, op. cit., v. III, p. 192.
} 
proprietários, do litoral aos sertões. Dado o seu potencial de resistência, era motivo freqüente de controle e preocupação por parte das autoridades. ${ }^{45}$

Todavia, a reprodução e o funcionamento da sociedade não se esgotavam nesses pólos. Uma análise sobre a documentação do período indica o registro crescente dos segmentos intermediários, constituídos por pobres de ambos os sexos e muitos ex-escravos envolvidos em variadas atividades produtivas, quando não se encontravam desprovidos de qualquer meio de subsistência, mas que em muitos momentos de tensão estiveram presentes na cena pública movidos pelas necessidades imediatas. ${ }^{46}$ Estes setores freqüentemente se viam constrangidos, seja pela violência do recrutamento forçado, do atraso no soldo das tropas, da falta de ocupação, da fome que os rondava ainda mais em períodos prolongados de secas, seja pela origem racial que os discriminava sobretudo no que diz respeito à organização das tropas. Semelhantes aos escravos, viviam no limite das condições de existência, não se beneficiando nos períodos de crescimento econômico e sendo ainda mais penalizados nos momentos de crise. ${ }^{47}$ As resultantes dessas profundas desigualdades para os indivíduos de menor condição na Bahia constituíram o cerne das críticas formuladas pelos líderes da sedição de 1798, cujo acontecimento e a violenta repressão que se seguiu sobre os acusados ainda eram bem recentes no momento em que o príncipe chegou à capitania.

Estudos já indicaram a influência das explosões revolucionárias de fins do século XVIII sobre o movimento, mormente a Revolução Francesa, a despeito do controle exercido pelas autoridades régias para coibir a circulação de idéias, livros e periódicos considerados nocivos. ${ }^{48}$ As tentativas da corte em ocultar as

\footnotetext{
${ }^{45}$ Cf. REIS, João José. Rebelião escrava no Brasil. A história do levante dos Malês em 1835. Ed. revista e ampliada. São Paulo: Companhia das Letras, 2003.

${ }^{46}$ Idem, ibidem (especialmente capítulo I).

${ }^{47}$ MORTON, Frederic W. O., op. cit.

${ }^{48}$ MATTOSO, Kátia. Presença francesa no movimento democrático baiano de 1798. Salvador: Itapuã, 1969; JANCSÓ, István. A sedução da liberdade. In: SOUZA, Laura de Mello e (Org.). História da vida privada no Brasil. Cotidiano e vida privada na América portuguesa. (Coleção dirigida por Fernando A. Novais). São Paulo: Companhia das Letras, 1997, p. 387-437 e Na Bahia, contra o Império. História do ensaio de sedição de 1798. São Paulo: Hucitec; Salvador: EDUFBa, 1996b; MORTON, Frederic, op. cit.; RUY, Affonso. A primeira revolução social brasileira (1798). 2a . Ed. Companhia Editora Nacional, 1978; MOTA, Carlos Guilherme. Idéia de revolução no Brasil (1789-1801). 4a. Ed. Estudo das formas de pensamento. São Paulo: Ática, 1996; TAVARES, Luis Henrique Dias. Da sedição de 1798 à revolta de 1824 na Bahia. Salvador: Edufba; São Paulo: UNESP, 2003. Ver também: COGGIOLA, Osvaldo (Org.). A Revolução Francesa e seu impacto na América Latina. São Paulo: Nova Stella/Editora da USP; Brasília: CNPq, 1990,
} 
informações acerca das experiências políticas em curso na América espanhola, nas primeiras décadas do Oitocentos, apontam que era preciso evitar a difusão das críticas às monarquias absolutistas. ${ }^{49}$ Numa época de intensas mudanças, a Coroa portuguesa tinha mesmo que redobrar a vigilância haja vista que as contestações ocorridas na América portuguesa (Minas e Bahia) demonstravam novos fundamentos que as diferenciavam de experiências anteriores: a crítica a forma de organização do poder e a perspectiva de sua substituição por outra. ${ }^{50}$ Além disso, dentre as alterações que se propagavam pelo mundo atlântico nesse final de século, uma delas, especialmente, dizia respeito à presença maciça dos escravos africanos na cena pública.

Com efeito, no bojo dos acontecimentos revolucionários na França, teve início, em 1791, a rebelião dos escravos na colônia francesa de Saint-Domingue (atual Haiti), a mais produtiva das Américas, que se desdobrou em um violento conflito até a independência da ilha caribenha em 1804 com a destruição do sistema escravista. Isso faria com que, a partir de então, os escravos não fossem vistos apenas como indivíduos, mas como sujeito coletivo, e como tal, propenso a rebeliões. Ademais, a expansão da agricultura na colônia americana propiciou o aumento da população cativa, especialmente de escravos africanos da mesma etnia, favorecendo a ampliação das revoltas no decorrer do século XIX. Kátia Mattoso, analisando 53 inventários com descrição de 582 escravos para os biênios de 1805-1806 e 1810-1811, cujos testamentos foram registrados em tabelionatos de Salvador, conclui pela existência de uma porcentagem menor de crioulos (nascidos na América portuguesa) o que indicaria, para ela, certa tendência em períodos de prosperidade. ${ }^{51}$ Referências à crescente população

em especial o artigo de Kátia Mattoso: "Bahia 1798: os panfletos revolucionários. Proposta de uma nova leitura”, p. 341-356. As diferentes interpretações sobre a natureza do evento de 1798 foram abordadas por JANCSÓ, István em "Na Bahia, contra o Império", op. cit., (Introdução) e "Bahia 1798: a hipótese de auxílio francês ou a cor dos gatos". In: FURTADO, Júnia Ferreira (Org.). Diálogos Oceânicos. Minas Gerais e as novas abordagens para uma história do Império ultramarino português. Belo Horizonte: Editora UFMG, 2001, p. 361-387.

${ }^{49}$ PIMENTA, João Paulo Garrido. A política hispano-americana e o Império português (18101817): vocabulário político e conjuntura. In: JANCSÓ, István (Org.). Brasil: Formação do Estado e da Nação. São Paulo: Hucitec/Fapesp; Ijuí: Ed. Unijuí, 2003, p. 123-139; SILVA, Luiz Geraldo Santos da. O avesso da Independência: Pernambuco (1817-1824). In: MALERBA, Jurandir (Org.). A Independência brasileira. Novas Dimensões. Rio de Janeiro: Ed. FGV, 2006, p. 343-384.

${ }^{50}$ Cf. JANCSÓ, István, 1997, op. cit., p. 389.

${ }^{51}$ Segundo a autora, $30,8 \%$ de escravos crioulos para os anos de $1805-1806$ e apenas $19,5 \%$ em 1810-1811. MATTOSO, Kátia M. de Queirós. Os escravos na Bahia no alvorecer do século XIX. Revista de História, v. XLVIII, n 97, ano XXV, São Paulo, 1974, p. 116. Sobre o medo da 
escrava na Bahia demonstram que era preciso estar atento às insatisfações que poderiam desencadear revoltas de proporções imprevisíveis.

No ano anterior à vinda de $\mathrm{d}$. João, uma tentativa de rebelião envolvendo escravos haussás de Salvador e do Recôncavo demandou empenho das autoridades para desbaratá-la. Respondia pelo governo da Bahia à época o $6^{\circ}$. conde da Ponte, o mesmo que recepcionou o príncipe regente, conhecido pela maneira severa com que tratava as questões referentes aos escravos na capitania. Morgado da casa da Ponte, João de Saldanha também era reconhecido como um dos mais ricos proprietários de gado, escravos, fazendas, sítios, engenhos no Recôncavo e pelos sertões da Bahia adentro, como também em Portugal. Em sua opinião, os escravos africanos "Gêges, Ussás e Nagôs" estavam entre as "Nações as mais guerreiras da Costa do Leste" e a capitania da Bahia ficava com a maior parte das importações que foram mais de oito mil em 1806. Acreditava que era preciso endurecer o controle sobre os cativos, informando à corte de Lisboa que havia adotado, desde que assumira o governo, uma série de providências "sobre a vigilância e rigorosa subordinação em que deve manter-se a imensa Escravatura" ${ }^{52}$

Contando com a delação de um escravo, o governador conseguiu reprimir os escravos rebeldes, cujas lideranças foram sentenciadas a muitos açoites e penas de degredo, cumprindo a decisão de Lisboa para que aplicasse as penas de maneira que os sediciosos aprendessem a não "violar os direitos de seus respectivos Senhores, mas também [não] perturbar a segurança e o sossego público, de que depende a conservação dos Estados". Depois disso, restringiu ainda mais a circulação de escravos e libertos, além de proibir as reuniões e festas africanas. Mas parece que isso não foi o suficiente para intimidar os escravos, pois, em

haitianização no Brasil: MOTT, Luiz. Escravidão, homossexualidade e demonologia. São Paulo: Ícone, 1988, p. 11-18; REIS, João José. Nos achamos em campo a tratar da liberdade: a resistência negra no Brasil Oitocentista. In: MOTA, Carlos Guilherme (Org.), op. cit., 2000, p. 241-263. Para o caso da Bahia, conforme assinala o autor, o maior número de escravos haussás e nagôs, muito mais aguerridos que outros grupos étnicos, propiciou o aumento de revoltas que somente "na primeira metade do século XIX, [seria] em número superior a duas dezenas". Op. cit., p. 246; RODRIGUES, Jaime. Infame comércio. Propostas e experiências no final do tráfico de africanos para o Brasil (1800-1850). Campinas: Ed. da Unicamp/Cecult, 2000, p. 50-62. Para uma análise ampla sobre a crise do escravismo no contexto da era das revoluções: BLACKBURN, Robin. $A$ queda do escravismo colonial: 1776-1848. Rio de Janeiro; São Paulo, s.n., 2002. Segundo esse autor, "em 1770 os escravos das Américas eram explorados mais intensamente do que qualquer outro grupo do mesmo tamanho em toda a história". Op. cit., p. 32.

${ }^{52}$ Ofício do conde da Ponte para o Visconde de Anadia, em 16 de julho de 1807, publicado por Braz do Amaral em Ignácio Accioli, op. cit., v. III, p. 230. 
1809, novamente protagonizaram um levante na capitania. Apesar de estarem em número mais expressivo que antes e conseguirem fugir para se aquilombar, os rebeldes foram eliminados durante as ações repressivas do governo. ${ }^{53}$

Desse modo, o controle sobre a população ou sobre a circulação de idéias opostas aos princípios do absolutismo monárquico era feito com extremo rigor. Em fins desse ano, a corte solicitou informações sobre o domicílio de vários franceses em Salvador desde que a esquadra de Jerônimo Bonaparte ali aportara, assim como a presença de "um certo abade francês que professa e publica opiniões perigosas e que podem conduzir a sérias conseqüências a que também se une o dizer-se que na Bahia há um grande número secreto de pessoas vendidas ao Partido Francês". Exigia-se a prisão do abade e o seu envio para a corte, a expulsão dos franceses do Brasil caso se confirmasse as suspeitas e o imediato conhecimento sobre os partidários da França. A ênfase na importância e na rapidez das medidas que deveriam ser adotadas revela a rigidez com a qual a Coroa tratava a questão: "S.A.R. julga escusado significar a V.Exa. e Sas. que serão responsáveis de qualquer frouxidão ou descuido que possa haver na execução destas Reais Ordens e que S.A.R. espera sem perda de tempo o resultado das averiguações e exames a que ordena que V.Exa. e Sas. procedam sem perda de tempo e sem menor descuido". ${ }^{54}$ Por essa época a Bahia possuía um governo interino em razão da morte do conde da Ponte ocorrida em 24 de maio de 1809. Era preciso, então, indicar um substituto à altura dos desafios impostos pela conturbada conjuntura. Ao que parece, é nessa perspectiva que se pode entender a nomeação do conde dos Arcos, dom Marcos de Noronha e Brito, para o governo da capitania no ano seguinte.

Todavia, a despeito da crise política que assolava os domínios das monarquias absolutistas e, em particular, havia imposto à Coroa portuguesa uma mudança de conseqüências imprevisíveis, a situação econômica da colônia, em fins do século XVIII, havia se alterado favoravelmente em razão dos processos revolucionários do período, especialmente a revolução de Saint Domingue

\footnotetext{
${ }_{53}^{5}$ Idem, loc. cit. A atuação do conde da Ponte na repressão aos escravos na Bahia foi analisada por João Reis em "Rebelião escrava do Brasil", op. cit., e "Escravos e coiteiros no quilombo do Oitizeiro. Bahia, 1806”. In: _ ; GOMES, Flávio dos Santos. Liberdade por um fio. História dos quilombos no Brasil. São Paulo: Companhia das Letras, 1996, p. 332-372. Ver também, MATTOSO, Kátia M. de Queirós. Ser escravo no Brasil. São Paulo: Brasiliense, 1982, p. 165. NEVES, Erivaldo Fagundes discute o morgado da casa da Ponte. Estrutura fundiária e dinâmica mercantil. Alto Sertão da Bahia, séculos XVIII e XIX. Salvador: EDUFBA; UEFS, 2005.

${ }^{54}$ Citado por SILVA, Ignácio Accioli de Cerqueira e, op. cit., p. 234.
} 
que interrompera o fornecimento de açúcar e café do maior produtor mundial. Além do mais, as tentativas para revitalização do comércio colonial, por essa época, começaram a apresentar os primeiros sinais com a introdução de novos produtos na pauta de exportação. É certo que os efeitos decorrentes das pressões francesas sobre as nações européias, e especialmente sobre Portugal, produziram sérias oscilações para a economia colonial, mormente os embargos impostos por Bonaparte, como já referido. Em carta ao conde da Ponte, em 25 de março de 1808, d. Fernando José de Portugal, então nomeado secretário de Estado dos Negócios do Brasil, comunica que o príncipe regente, a fim de animar e proteger o comércio, determinou que fosse informado aos negociantes da praça da Bahia para aprontarem os navios com destino para as ilhas dos Açores e portos da Grã-Bretanha e Gibraltar, aproveitando algumas embarcações de guerra em passagem por aquele porto. ${ }^{55}$ Aos poucos, a abertura dos portos possibilitava a retomada do crescimento.

No caso da Bahia, estudos apontam que a medida contribuiu para a recuperação das receitas das exportações "e seu crescimento entre 1809 e 1816 " ${ }^{56}$ O açúcar, de longe o produto mais importante no comércio de exportação da capitania, superou um longo período de depressão e nas últimas décadas do século XVIII iniciou um processo de crescimento somente interrompido em princípios dos anos 1820 por ocasião da guerra de Independência quando a economia local sofreu novos abalos, se recuperando, porém, no final dessa década. Dominando as áreas de produção do açúcar, notadamente no Recôncavo baiano que concentrava a maior parte dos engenhos, os grandes proprietários rurais constituíram um poderoso grupo econômico que, mesmo não atuando de maneira coesa, soube utilizar o seu poder junto aos setores do governo desempenhando um papel importante nos acontecimentos políticos da capitania após a instalação da família real no Centro-Sul.

Não restam dúvidas que Salvador e o Recôncavo dominavam a paisagem econômica da capitania mantendo uma relação de complementaridade com as povoações situadas nos vastos sertões e nas freguesias localizadas ao sul que,

\footnotetext{
${ }^{55}$ APEB. Seção de Arquivo Colonial e Provincial. Ordens Régias. Maço: 105 (1808-1809). Em 8 de abril de 1808, d. Fernando José de Portugal comunicou ao conde da Ponte que o príncipe regente aprovou as suas medidas em não efetuar a ronda militar e o auto-exame em uma galera inglesa tendo em vista que essas ordens estavam suspensas desde a permissão para a entrada de navios estrangeiros nos portos do Brasil. Loc. cit.

${ }^{56}$ BARICKMAN, Bert J., op. cit., p. 53.
} 
a despeito de possuírem sua dinâmica interna, atuavam como sustentáculo de uma economia voltada essencialmente para o comércio de exportação. Em determinados momentos de alteração das necessidades econômicas do mercado europeu, como no final do século XVIII e princípios do Oitocentos, essas regiões foram incorporadas ao circuito comercial da exportação, a exemplo do cultivo do algodão e do café, redefinindo as condições de inserção das populações interioranas nos quadros da economia baiana. ${ }^{57}$

Essa geografia econômica da capitania da Bahia é essencial para a apreensão das articulações políticas que se estabeleceram entre os grupos econômicos locais e o príncipe regente no contexto de crise do absolutismo monárquico e de reordenamento do Império português. Ciosos do lugar que ocupavam nessa estrutura, os proprietários se predispuseram a assegurar a preservação dos interesses da Coroa desde que os seus pudessem ser contemplados. Isto não significou a inexistência de conflitos entre as frações de uma mesma classe, sobretudo em momentos de crise que favoreciam a elaboração de distintos projetos políticos, assim como o estabelecimento de alianças diante de situações reais de ameaça do seu status quo econômico e político.

Em 30 de setembro de 1810, pouco mais de dois anos após a vinda da família real, o conde dos Arcos assumiu o governo da Bahia, após ter governado o Pará (1803-1806) e ocupado o cargo de último Vice-Rei no Rio de Janeiro, permanecendo cerca de oito anos no comando da capitania. A conjuntura política daquele ano apresentou fortes revezes para o absolutismo espanhol, tendo em vista que importantes cabildos nas colônias americanas instituíram juntas provisórias de governo com o propósito de substituir os representantes designados pelo poder metropolitano: Caracas (19 de abril); Buenos Aires (25 de maio); Bogotá (20 de julho) e Santiago do Chile em 18 de setembro. Experiências que foram posteriormente adotadas nas principais províncias do Brasil após a Revolução Constitucionalista do Porto.

Nesse mesmo ano, a Coroa portuguesa assinou o Tratado de Comércio com a Grã-Bretanha estabelecendo o porcentual de 15\% sobre as mercadorias importadas para o Brasil, favorecendo-a em detrimento dos comerciantes portugueses que até 1818 pagaram 16\% sobre suas importações. O tratado reconhecia, na prática, o apoio que o príncipe regente recebera da poderosa rival da França,

\footnotetext{
${ }^{57}$ BARICKMAN, Bert J., op. cit; NEVES, Erivaldo Fagundes. Estrutura fundiária e dinâmica mercantil. Alto Sertão da Bahia, séculos XVIII e XIX. Salvador: EDUFBA; UEFS, 2005.
} 
reforçando os laços de aliança estabelecidos desde o aprofundamento da crise na península Ibérica. A medida desagradou sobremaneira os portugueses que se viram preteridos diante das vantagens concedidas aos ingleses, cuja penetração no comércio da Bahia já havia sido criticada quando o príncipe regente esteve na capitania, como mencionado. Já em fins de 1808, d. Fernando José de Portugal, a pedido do príncipe regente, remetera para o conde da Ponte uma carta do cônsul geral da Grã-Bretanha na qual se queixa do tratamento recebido pelos ingleses em Salvador e em Pernambuco, requerendo informações sobre o assunto. Além disso, determinava que a alfândega cumprisse os avisos em benefícios dos ingleses conforme havia sido expedido. ${ }^{58}$ As céleres mudanças no cenário mundial e as alterações decorrentes recomendavam cautela e habilidade nas intervenções.

Nesse contexto, a indicação do conde dos Arcos aparece como parte de uma estratégia mais ampla da Coroa: assegurar os laços de adesão de parte dos residentes da Bahia por meio da mediação de um dos mais importantes funcionários régios da monarquia bragantina. De fato, o período em que comandou a capitania coincide com os anos de aprofundamento do processo de reordenamento do Estado português diante dos acontecimentos externos, no qual a elevação do Brasil a Reino Unido constitui um marco significativo, bem como a eclosão do mais importante movimento contrário à política centralizadora do Rio de Janeiro, antes da Independência, que teve Pernambuco como palco principal e a Bahia uma aliada em potencial.

Nas descrições sobre o conde dos Arcos, ele aparece como um inquieto governador que em poucos anos de administração (seu governo se encerrou em 26 de janeiro de 1818) conseguiu investir em diferentes setores econômicos da capitania, a exemplo do comércio e da produção agrícola, além da abertura de estradas, criação de vilas, estabelecimento de correios, entre outras intervenções que aprimorassem as comunicações no interior da vasta capitania, facilitando a circulação de mercadorias, homens e animais. Nessas novas condições, negociantes, senhores de engenho e indivíduos viram a possibilidade de garantir os seus interesses usufruindo os benefícios que as novas condições poderiam proporcionar. É nessa época que se instalou o primeiro engenho a vapor na Bahia, a Casa do Comércio que visava congregar os negociantes de Salvador, a tipografia responsável pela primeira gazeta da Bahia (A Idade d'Ouro do

\footnotetext{
${ }^{58}$ APEB. Seção de Arquivo Colonial e Provincial. Ordens Régias. Maço: 105 (1808-1809).
} 
Brazil) e a segunda do Brasil, e a filial do Banco do Brasil. Ademais, tentou estabelecer uma política de tratamento mais flexível em relação aos escravos enfrentando forte oposição. ${ }^{59}$

A rigor, o empenho do capitão-general para dotar a capitania e, sobretudo, a cidade de Salvador dos recursos materiais condizentes com os novos tempos - a presença da monarquia portuguesa em terras americanas -, auxiliado pelas iniciativas de empreendedores locais motivados pelas circunstâncias, se daria também no campo do aprimoramento da segurança local e de novas estratégias para assegurar a preservação da ordem interna e de possíveis ataques de inimigos externos. A ampliação considerável das forças militares, bem como as discussões sobre o papel das forças armadas na década de 1810, apontam para a valorização desse segmento, perspectiva, aliás, que contava com o apoio dos proprietários locais. Ao que parece, a questão central aqui era que o receio das rebeliões escravas motivava mais os senhores do que um possível ataque de forças inimigas externas e isso tinha vinculação direta com a natureza das forças armadas. ${ }^{60}$

De qualquer maneira, a atuação do brigadeiro Felisberto Caldeira Brant Pontes como Inspetor Geral das Tropas (1811-1821), ele próprio um grande proprietário de terras e escravos, mostra que a questão da segurança na Bahia, a despeito das constantes queixas para atingir o rigor desejado entre os oficiais, teve nesse período uma centralidade fundamental. Além disso, é preciso ressaltar que embora o debate sobre as forças armadas não tenha sido isento de tensões entre o Estado e os proprietários, como argumenta Hendrik Kraay, eles se mantiveram coesos ao lado do monarca e contrários a qualquer ameaça vinda dos homens de menor condição. ${ }^{61}$

\section{Restauração e Reino Unido}

O desenrolar do conflito na Europa era acompanhado na corte do Rio de Janeiro à medida que as notícias chegavam pelas embarcações. Já em 9 de

\footnotetext{
${ }^{59}$ MORTON, F.W.O.. The governorship of the Count of Arcos in Bahia, 1810-1818. Enlightened despotism in an age of revolution, Toronto: outubro de 1986 (mimeog.). Agradeço ao prof. João José Reis a cessão da cópia desse texto. Apesar da sintonia em algumas inovações implantadas nesse período, o conde dos Arcos e Caldeira Brant tiveram sérias divergências sobre as estratégias para o controle da escravaria. João José Reis observa que não obstante os métodos menos rigorosos utilizados pelo conde dos Arcos em relação aos escravos, ele não conseguiu evitar que revoltas importantes ocorressem durante a sua gestão. REIS, João José, 2003, op. cit., p. 91.

${ }^{60}$ KRAAY, Hendrik, op. cit., (especialmente capítulo 2).

${ }^{61}$ Idem, p. 32.
} 
dezembro de 1808, o príncipe regente comunicou ao conde da Ponte que fora informado das duas derrotas que os ingleses e portugueses haviam imposto ao exército francês e da capitulação de Junot-- e que todos os dias aguardava navios de Lisboa para obter notícias sobre a restauração daquela capital e de todo o reino. Pouco mais de um mês depois, d. João recomendava que o governador providenciasse os festejos em comemoração à total libertação dos reinos de Portugal e Algarves do domínio francês. ${ }^{62}$

A notícia teve um impacto direto sobre o comércio da capitania que a partir de então poderia enviar seus navios para os portos de Portugal, conforme determinação da corte. ${ }^{63}$ Mas as tropas francesas ainda promoveriam duas incursões no Reino europeu, em 1809 e em 1810. Anos mais tarde, por ocasião da abdicação de Napoleão Bonaparte em 6 de abril de 1814, as notícias eram ainda mais promissoras e o príncipe regente ordenava que diante do término das hostilidades entre as potências beligerantes:

[...] de em diante nos portos dessa capitania todas as embarcações francesas e das outras potências que por se acharem sujeitas ao seu domínio ou influência se consideravam inimigas de Portugal, determinando que tais embarcações se recebam como amigas, facilitando-se-lhes aquele comércio que está permitido atualmente às nações em paz e amizade com esta corte; e em reciprocidade ficam habilitados todos os vassalos Portugueses para seguirem com os seus navios a qualquer porto pertencente aos domínios daquelas nações [...]..$^{64}$

Como se sabe, o general francês ainda enfrentaria o exército das potências aliadas (Grã-Bretanha, Rússia, Áustria e Prússia) sendo finalmente derrotado na batalha de Waterloo, em 18 de julho de $1815 .{ }^{65}$ O Congresso de Viena, reunido

\footnotetext{
${ }^{62}$ APEB. Seção de Arquivo Colonial e Provincial. Ordens Régias. Maço: 105 (1808-1809). No mesmo dia, 20 de dezembro de 1808, o príncipe requeria as listas dos donativos que os lavradores de tabaco da vila de Cachoeira ofereceram aos habitantes de Portugal, enquanto durasse a guerra, sugerindo que a cobrança fosse feita a outros lavradores que se comprometeram com a mesma oferta. Loc. cit.

${ }^{63}$ APEB. Seção de Arquivo Colonial e Provincial. Ordens Régias. Maço: 105 (1808-1809).

${ }^{64}$ Carta de Antônio de Araújo de Azevedo, em 18 de junho de 1814, para o conde dos Arcos. Citada por SILVA, Ignácio Accioli de Cerqueira e, op. cit., p. 192-193.

${ }^{65}$ Napoleão foi aprisionado na ilha de Santa Helena, a quilômetros de distância da Europa. Portugal contestou o local de reclusão do ex-imperador em razão da proximidade da ilha das possessões africana e americana. Cf. Oliveira Lima, op. cit. Em 31 de janeiro de 1816, o marquês de Aguiar,
} 
desde o ano anterior para redefinir o mapa da Europa e restaurar as monarquias destituídas dos seus tronos, sob o princípio da legitimidade dinástica, buscava medidas preventivas para evitar a expansão das idéias liberais a esta altura já bastante difundidas, em meio a outras decisões fundamentais nesse novo contexto. Dentre elas, a proposta de abolição do tráfico de escravos ao norte do Equador sustentada principalmente pela Grã-Bretanha.

As articulações da corte do Rio de Janeiro para evitar a proposição por meio dos seus representantes diplomáticos não surtiram efeito, frustrando a perspectiva de Portugal de estabelecer uma aliança com a Rússia sobre a questão, além de evidenciar a sua fragilidade política. Para os negociantes da Bahia, a medida era extremamente nociva. Afinal, a Bahia era uma das principais praças na movimentação desse comércio. Em 29 de agosto de 1815, a gazeta Idade d'Ouro do Brazil divulgava que: "A conversão e o Tratado de Abolição do tráfico de escravos ao Norte do Equador, assinados em Viena a 21 e 22 de janeiro de 1815, acham-se à venda na loja de José Felipe dos Santos, [...] assim como o Tratado de Amizade e Aliança assinado no Rio de Janeiro em fevereiro de 1810" ${ }^{66}$ Uma demonstração de que as notícias eram acompanhadas com interesse.

As resoluções do evento possuíam vinculação direta com a situação do Império português e o retorno ao equilíbrio europeu interferia diretamente nos rumos da Coroa após as conturbadas mudanças dos últimos anos. Em outras palavras, a queda definitiva de Napoleão Bonaparte dissipara os obstáculos que poderiam impedir a volta da Corte. O monarca finalmente teria que decidir entre cessar o descontentamento dos portugueses europeus em razão da sua presença na América e ao mesmo tempo evitar que o retorno significasse uma porta aberta para o avanço das idéias de independência que, nesse momento, estavam em pleno vigor nas áreas hispano-americanas.

De fato, os acontecimentos em curso nessas localidades expunham profundamente a crise do Antigo Regime ao possibilitar formas diferenciadas de práticas políticas que não poderiam ser desprezadas pelos ministros de d. João em suas

ministro dos Negócios Estrangeiros, encaminhou correspondência ao conde dos Arcos alertando sobre a proibição de navios circularem na área da ilha de Santa Helena e requerendo que todos os comerciantes daquela praça fossem comunicados. APEB. Seção de Arquivo Colonial e Provincial. Cartas do Senado a Sua Majestade. Maço: 132 (1742-1823).

${ }^{66}$ APEB. Setor de Microfilmes. Idade d'Ouro do Brazil, n. 69, 29 de agosto de 1815. Os acontecimentos na Europa e na América hispânica, assim como os desdobramentos do Congresso de Viena também foram noticiados pelo periódico. 
formulações sobre o futuro da dinastia de Bragança. Alguns meses após o fim do congresso, em 16 de dezembro de 1815, o príncipe regente assinou a Carta de Lei elevando o Brasil à condição de Reino Unido a Portugal e Algarves. Para os residentes da parte americana, a medida reconhecia, na prática, a sua importância no interior do Império português ampliando a noção de pertencimento a uma mesma identidade política que unia os portugueses dos dois lados do atlântico. ${ }^{67}$ Para a Coroa, uma tentativa de preservação da monarquia em meio à crise de desestruturação dos antigos padrões de sustentação do poder político.

Mas as questões políticas constituíam um empecilho à pretendida unidade no interior da nação portuguesa, resultando em diferentes manifestações pela decisão do príncipe. Enquanto em Portugal, os setores mercantil e manufatureiro, além da nobreza, reclamavam a ausência do monarca e reagiam contra a nova medida agravando ainda mais o clima de insatisfação; no Brasil, a notícia da elevação foi recebida com celebrações e regozijos em diversas vilas e cidades. No Rio de Janeiro, os principais da Corte se reuniram em um festivo beija-mão e a cidade ficou iluminada durante três dias. Em Pernambuco, o governador ordenou festejos à altura do evento. Recife e Olinda foram iluminadas, realizou-se o Te Deum e uma das praças foi rebatizada com o nome de Praça da União. O senado da Câmara de Salvador informou ao príncipe regente, em 13 de março de 1816, sobre as muitas comemorações realizadas na cidade, além do envio de dois representantes para cumprimentá-lo pela elevação, e a gazeta Idade d'Ouro do Brazil tornava público as notícias dos festejos, divulgando edital da Câmara que conclamava a população para as festas, assim como a lista de comerciantes que comemoraram a decisão do príncipe ${ }^{68}$ Por meio dessas ações, parte dos residentes da Bahia demonstrava seus laços de adesão ao monarca.

\footnotetext{
${ }^{67}$ JANCSÓ, István; PIMENTA, João Paulo G., op. cit.

${ }^{68}$ APEB. Seção de Arquivo Colonial e Provincial. Cartas do Senado a Sua Majestade. Maço: 132 (1742/1823). Em outra correspondência, o marquês de Aguiar cumprimenta o governador pela decisão de suspender as comemorações em razão da morte da rainha, d. Maria I. APEB. Seção de Arquivo Colonial e Provincial. Cartas Régias enviadas à capitania da Bahia. Maço: 118 (1816). Para as notícias sobre as comemorações: APEB. Setor de Microfilmes. Idade d'Ouro do Brazil, $\mathrm{n}^{\mathrm{o}}$ 17, 27 de fevereiro de 1816 . Na edição de $1^{\circ}$. de março, o periódico ressaltava que: "A pressa com que escrevemos a folha passada não nos permitiu fazer uma descrição exata de tudo que se passou nesta Cidade nos dias da sua Gratificação à Mercê, que S. A. R. fez ao Estado do Brazil. Dentre algumas coisas que nos escaparam lembramos agora uma, que seria ingratidão, e injustiça omitir; e é que os Navios surtos neste Porto se embandeiraram com muita variedade, e galhardia; e a maior parte deles deram estrondosas salvas por várias vezes, sem que o Senado fizesse nisso a menor despesa. Foi pura devoção, e reconhecimento particular de seus Donos”. Maria de
} 
Assim como 1808, a elevação do Brasil a Reino possui uma significância que extrapola os interesses circunstanciais da Coroa portuguesa, pois, ambos, vinculam-se às demandas de um mundo convulsionado nessas primeiras décadas do Oitocentos. Para os portugueses americanos, em especial, o Brasil Reino forneceu uma nova dimensão política pelo que representou em termos de inovação dos seus referenciais políticos. Contudo, esse movimento não se daria de maneira uniforme entre as distintas capitanias subordinadas horizontalmente ao Rio de Janeiro, possibilitando potencializar as diferenças internas. ${ }^{69}$ Era preciso aprofundar as conquistas obtidas e, nesse aspecto, parte dos residentes da Bahia demonstrará a fragilidade dos laços de adesão que os unia ao monarca quando confrontados com a preservação de seus próprios interesses. Desse modo, a intensidade das mudanças decorrentes da Revolução Constitucionalista do Porto, em princípios dos anos 1820, facultou que posições enraizadas e desejos represados viessem à tona, evidenciando, assim, que a rearticulação dos vínculos dependeria de um novo pacto.

\section{Referências bibliográficas}

ARTOLA, Miguel. Antiguo Régimen y Revolucion liberal. Madri, 1979.

ARRUDA, José Jobson de Andrade. Uma colônia entre dois Impérios. A abertura dos portos brasileiros, 1800-1808. São Paulo: Edusc, 2008.

BANDEIRA, Luiz Alberto Moniz. O feudo. A casa da Torre de Garcia d'Ávila: da conquista dos Sertões à Independência do Brasil. Rio de Janeiro: Civilização Brasileira, 2000.

BARICKMAN, Bert J. Um contraponto baiano. Açúcar, fumo, mandioca e escravidão no Recôncavo, 1780-1860. Rio de Janeiro: Civilização Brasileira, 2003.

BLACKBURN, Robin. A queda do escravismo colonial: 1776-1848. Rio de Janeiro/ São Paulo, s.n. 2002.

BRITO, João Rodrigues de. et al. Cartas econômico-políticas sobre agricultura e comércio da Bahia. Lisboa: Imprensa Nacional, 1821.

COGGIOLA, Osvaldo (Org.). A Revolução Francesa e seu impacto na América

Lourdes Viana Lyra aborda as reações manifestadas por portugueses europeus e americanos após a elevação do Brasil a Reino. Op. cit.

${ }^{69}$ Cf. JANCSÓ, István; PIMENTA, João Paulo G., op. cit. Wilma Peres Costa discute as resistências das províncias para o envio de recursos, oriundos, sobretudo das tarifas de exportação, ao Rio de Janeiro. "A economia mercantil escravista nacional e o processo de construção do Estado no Brasil (1808-1850)”. In: SZMRECSÁNYI, Tamás; LAPA, José Roberto do Amaral (Orgs.), op. cit., p. 147-159. 
Latina. São Paulo: Nova Stella/Editora da USP; Brasília: CNPq, 1990.

COSTA, Wilma Peres. A economia mercantil escravista nacional e o processo de construção do Estado no Brasil (1808-1850). In: SZMRECSÁNYI, Tamás; LAPA, José Roberto do Amaral (Orgs.). História econômica da Independência e do Império. São Paulo: Hucitec, 1996, p. 147-159.

FONTANA, Josep. La crisis del Antiguo régimen, 1808-1833. 2ª Ed. Barcelona: Editorial Crítica, 1982.

GODECHOT, Jaques. Europa e América no tempo de Napoleão (1800-1815). São Paulo: Pioneira; Edusp, 1984.

HALPERIN DONGHI, T. História da América Latina. $3^{\mathrm{a}}$. Ed. Rio de Janeiro: Paz e Terra, 1975.

HOBSBAWN, Eric J. A era das revoluções. 9a. Ed. Rio de Janeiro: Paz e Terra, 1994.

JANCSÓ, István; PIMENTA, João Paulo G. Peças de mosaico (ou apontamentos para o estudo da emergência da identidade nacional brasileira). In: MOTA, Carlos Guilherme (Org.). Viagem Incompleta. A experiência brasileira (15002000). Formação: histórias. São Paulo: Senac, 2000, p. 152-153.

Bahia 1798: a hipótese de auxílio francês ou a cor dos gatos. In: FURTADO, Júnia Ferreira (Org.). Diálogos Oceânicos. Minas Gerais e as novas abordagens para uma história do Império ultramarino português. Belo Horizonte: Editora UFMG, 2001, p. 361-387.

A construção dos Estados nacionais na América Latina. Apontamentos para o estudo do Império como projeto. In: SZMRECSÁNYI, Tamás; LAPA, José Roberto do Amaral (Orgs.). História econômica da Independência e do Império. São Paulo: Hucitec, 1996.

Na Bahia, contra o Império. História do ensaio de sedição de 1798. São Paulo: Hucitec; Salvador: EDUFBA, 1996.

A sedução da liberdade. In: SOUZA, Laura de Mello e. (Org.). História da vida privada no Brasil. Cotidiano e vida privada na América portuguesa. (Coleção dirigida por Fernando A. Novais). São Paulo: Companhia das Letras, 1997, p. 387-437.

KRAAY, Hendrik. Race, State and Armed Forces in Independence-era Brazil. Bahia, 1790s-1840s. Stanford: Stanford University Press.

LYRA, Maria de Lourdes Viana. A utopia do poderoso Império. Portugal e Brasil: Bastidores da política, 1798-1822. Rio de Janeiro: Sette Letras, 1994.

MATTOSO, Kátia M. de Queirós. Bahia século XIX: uma província no Império. $2^{a}$. ed. Rio de Janeiro: Nova Fronteira, 1992.

MATTOSO, Kátia M. de Queirós. Presença francesa no movimento democrático baiano de 1798. Salvador: Itapuã, 1969.

MATTOSO, Kátia M. de Queirós. Os escravos na Bahia no alvorecer do século 
XIX. Revista de História, v. XLVIII, no 97, ano XXV, São Paulo, 1974.

MATTOSO, Kátia M. de Queirós. Ser escravo no Brasil. São Paulo: Brasiliense, 1982.

MORTON, Frederic W.O. The Conservative Revolution of Independence: Economy, society and politics in Bahia (1790-1840). University of Oxford, 1974.

MORTON, Frederic W.O. The governorship of the Count of Arcos in Bahia, 18101818. Enlightened despotism in an age of revolution. Toronto: outubro de 1986 (mimeog.).

MOTA, Carlos Guilherme. Idéia de revolução no Brasil (1789-1801). 4ª . ed. Estudo das formas de pensamento. São Paulo: Ática, 1996.

NEVES, Erivaldo Fagundes. Estrutura fundiária e dinâmica mercantil. Alto Sertão da Bahia, séculos XVIII e XIX. Salvador: EDUFBA; UEFS, 2005.

NORTON, Luís. A corte de Portugal no Brasil. 2a. Ed. São Paulo: Companhia Editora Nacional; Brasília: INL, 1979.

NOVAIS, Fernando A. Portugal e Brasil na crise do Antigo Sistema Colonial (1777-1808). São Paulo: Hucitec, 1983.

OLIVEIRA LIMA, M. D. João VI no Brasil. $3^{\text {a }}$. Ed. Rio de Janeiro: Topbooks, 1996.

PIMENTA, João Paulo Garrido. Estado e nação no fim dos impérios ibéricos no Prata (1808-1828). São Paulo: Hucitec; Fapesp, 2002.

PIMENTA, João Paulo Garrido. A política hispano-americana e o Império português (1810-1817): vocabulário político e conjuntura. In: JANCSÓ, István (Org.). Brasil: Formação do Estado e da Nação. São Paulo: Hucitec/Fapesp; Ijuí: ed. Unijuí, 2003, p. 123-139.

PINHO, Wanderley. A abertura dos portos. Cairu. Os Ingleses. A Independência. Salvador: Publicações da Universidade da Bahia, 1961.

PINTO DE AGUIAR. A abertura dos portos do portos do Brasil. Cairu e os ingleses. Livraria Progresso Editora. Edição conjunta com a Câmara Municipal da cidade do Salvador, 1960.

REIS, João José. Rebelião escrava no Brasil. A história do levante dos Malês em 1835. Ed. revista e ampliada. São Paulo: Companhia das Letras, 2003.

REIS, João José. Escravos e coiteiros no quilombo do Oitizeiro. Bahia, 1806. In: ; GOMES, Flávio dos Santos. Liberdade por um fio. História dos quilombos no Brasil. São Paulo: Companhia das Letras, 1996, p. 332-372.

REIS, João José. Nos achamos em campo a tratar da liberdade: a resistência negra no Brasil Oitocentista. In: MOTA, Carlos Guilherme (Org.). Viagem Incompleta. A experiência brasileira (1500-2000). Formação: histórias. São Paulo: Senac, 2000, p. 241-263.

RÉMOND, René. O século XIX (1815-1914). São Paulo: Cultrix, 1976. 
ROCHA, Antônio Penalves. Economia política e política no período joanino. In: SZMRECSÁNYI, Tamás; LAPA, José Roberto do Amaral. (Orgs.). História econômica da Independência e do Império. São Paulo: Hucitec, 1996, p. 31-32.

ROCHA, Antônio Penalves. A economia política na sociedade escravista. São Paulo: Hucitec/USP, 1996.

SANTOS, Luis Gonçalves dos. Memórias para servir à História do Reino do Brasil. Belo Horizonte: Itatiaia; São Paulo: Edusp, 1981.

SILVA, Ignácio Accioli de Cerqueira e. Memórias históricas e políticas da província da Bahia (anotadas por Braz do Amaral). Bahia: Imprensa Oficial do Estado, 1931, v. III.

SILVA, Luiz Geraldo Santos da. O avesso da Independência: Pernambuco (18171824). In: MALERBA, Jurandir (Org.). A Independência brasileira. Novas Dimensões. Rio de Janeiro: Ed. FGV, 2006, p. 343-384.

SILVA, Maria Beatriz Nizza da. A primeira gazeta da Bahia: Idade d'Ouro do Brazil. 2a ${ }^{\text {a }}$ Ed. revista e ampliada. Salvador: EDUFBA, 2005.

SOUZA, Avanete Pereira. Poder político local e cotidiano: a Câmara de Salvador no século XVIII. Dissertação (Mestrado em História). Universidade Federal da Bahia, Salvador, 1996-2001.

TAVARES, Luis Henrique Dias. História da Bahia. 10ª . Ed. São Paulo: Editora Unesp; Salvador: EDUFBA, 2001.

TAVARES, Luis Henrique Dias. Da sedição de 1798 à revolta de 1824 na Bahia. Salvador: EDUFBA; São Paulo: Unesp, 2003.

Recebido: março/2008 - Aprovado: setembro/2008 